Meta

Journal des tradlucteurs

Translators' Journal

\title{
Literary Translation in Canada: A Survey
}

Philip Stratford

Volume 22, numéro 1, mars 1977

Histoire de la traduction au Canada

URI : https://id.erudit.org/iderudit/004307ar

DOI : https://doi.org/10.7202/004307ar

Aller au sommaire du numéro

Éditeur(s)

Les Presses de l'Université de Montréal

ISSN

0026-0452 (imprimé)

1492-1421 (numérique)

Découvrir la revue

Citer cet article

Stratford, P. (1977). Literary Translation in Canada: A Survey. Meta, 22(1),

37-44. https://doi.org/10.7202/004307ar d'utilisation que vous pouvez consulter en ligne.

https://apropos.erudit.org/fr/usagers/politique-dutilisation/ 


\section{Literary Translation in Canada: A Survey*}

It must seem strange that a country like ours which has accepted the idea of fostering two languages and two cultures for over 200 years should have made such a small contribution in the way of translation, but the fact is that we lag behind most Western nations in this field. UNESCO statistics show Canada ranking somewhere between Iceland and Albania in annual production ${ }^{2}$. Historically, next to no literary translation was published in Canada before 1920 (10 titles in English, 2 in French), and little enough during the next forty years (39 titles in English, 9 in French). There never has been any systematic attempt to translate major works of the other culture. Too often Canadians have not only been guilty of ignoring each other ; they have struck the colonial posture and have left the initiative of translating Canadian books to foreign translators publishing in London, Paris or New York ${ }^{2}$. In short, there is no tradition of literary translation in Canada.

The picture has brightened during the past fifteen years thanks to a federal support programme administered by the Canada Council. The number of translations has increased dramatically; quality has improved; translation of Canadian works has been largely repatriated. It is too early, however, to call this trend the start of a tradition. Little is known about how effective the translation programme has been in stimulating public interest in the other culture. And one feels sure that if the support were withdrawn, work in this field would rapidly dwindle to pre1960 levels.

Although Canada has as yet no tradition in literary translation, still translation here has a history. It may be said to begin after the conquest with versions of royal proclamations destined for the French-speaking populace. The legal

* In this article I deal only with translation from French to English and vice versa.

1. UNESCO Statistical Yearbooks, 1968, 1971, 1974. For the decade 1963-1972 Canada averaged 117 translations per year; Iceland 149; Albania 97. These statistics include books of all kinds, and * religious * books account for $25 \%$ of Canada's total while - literature $\gg$ represents only $20 \%$. Although there has been a slight increase in the number of Canadian translations over this decade, the world rate has also increased, so that compared to other nations Canada actually dropped from 46th percentile in 1966 to $43 \mathrm{rd}$ in 1973. As a point of comparison with European countries, Belgium publishes 8 times as many translations as Canada; Switzerland 7 times; Hungary 8 times; and the Netherlands 16 times as many.

2. Prior to 1960 a total of 21 French-Canadian titles were translated and published in Britain or the States, as opposed to 49 published in Canada ; for the same period 12 English-Canadian titles were published in France, 11 in Quebec. 
rather than the literary quality of such translations was what counted, the information they carried rather than the style of their presentation. This type of anonymous bureaucratic translation has absorbed most of the energies of Canadian translators ever since. A large, costly, and highly trained establishment of translators still functions in Ottawa, and to a lesser extent in provincial capitals, providing the multitudinous services that the government of an officially bilingual country requires. Over 100000 documents of this nature are preserved in the public archives. The history, even a stylistic study, of this mass of material would undoubtedly be interesting to pursue, but it need not detain us now. Suffice it to say that very few of these thousands of skilled professional translators have ever shown any inclination to attempt to translate work of a literary nature ${ }^{3}$. Due to the inexhaustible mountain of work to be done, a strictly pragmatic attitude dominates the profession in this country. Most talented translators are trained to fill full-time posts in the civil service or in the private sector; they spend their lives as anonymous, competent, well-paid functionaries; as a corollary, literary translation is looked upon as a marginal activity, slightly frivolous, and economically uninteresting ${ }^{4}$.

Turning towards literary history, one might say, taking a large view and considering content rather than place of origin, that even pre-dating the first bureaucratic translations come European translations of explorers' journals and travellers' reports. I have argued elsewhere ${ }^{5}$ that this material should be considered part of our national literature, indeed that it is the Canadian equivalent of an epic tradition in older European civilizations ${ }^{6}$. Two things are noteworthy in respect to these translations : First, they represent a continued European interest in Canada - which is quite a different thing from a Canadian view of the same reality. Curiosity about the opening of the New World assured a steady stream of translations : Cartier was translated in London as early as 1580, Lescarbot in 1609, Hennepin in 1698, Lahonton 1703, Charlevoix 1761, La Salle 1844; Champlain 1878, and the Jesuit Relations in 73 volumes from 1896 to 1901 , the latter two titles published in the U.S. In fact, the bulk of translation done in the $17^{\text {th }}, 18$ th and 19 th centuries is of this nature. Moreover, the image of Canada as a somewhat exotic object for distant Old World scrutiny persists right into the 20th century and conditions the choice of Canadian works deemed suitable for European translation and consumption.

The second interesting cultural fact is that whereas practically all of the works of French explorers and travelers have been Englished, very few of those by the

3. The one notable exception is Harry Lorne Binsse, who worked for many years in the translation service of the Quebec government and translated Pierre le magnifique by Lemelin and 4 novels by Gabrielle Roy as well as several French novels.

4. Although Canadian literary translators are well-paid by world standards (the top Canada Council rate is $5 \phi$ per word), their commercial counterparts working d la pige receive three to four times as much.

5. \& Littérature canadienne d'expression anglaise, \& Cyclopedia Universalis, III, 866.

6. Maureen Newman and $I$, in our Bibliography of Canadian Books in Translation : French to English and English to French... (HRCC, Ottawa), 1975, have devoted a special section to a Letters, Reports, Travel Journals $*$. This bibliography, augmented by research which will be incorporated in a revised edition in 1977, provides the basis for most of the information included in this article. 
English navigators and the explorers of the Canadian West have been rendered into French. The causes and effects of such a fact may be difficult to calculate, but one must observe, as far as the country as a whole is concerned, that its history is far more accessible in English than in French.

When we turn to translations of works that are more conventionally literary (fiction, poetry, drama, essays), we find that the phenomena we have begun to observe apply as well. Statistically speaking translations from French to English have always outnumbered those in the reverse direction, by about 2 to 1 ? This is about the same proportion as the division of Canada's population into Englishspeaking and French-speaking parts, but such an analogy is deceptive. One might very well expect the ratio of translation to be reversed, the economically and demographically stronger part of the country taking upon itself the responsibility of seeing that English works appear in translation on the French market. Such is not, however, the case and one must briefly examine the reasons for this cultural disparity.

On the one hand, Quebec's minority situation has always been coupled with a certain xenophobia, particularly directed to the rest of the country. When the question of contact with la culture anglo-saxonne arises, there is a stronger attraction to its American expression to the South than to its Canadian expression to east or west. The stock response to the question why more English-Canadian works are not translated in Quebec is that competition from American and even British sources overshadows Canadian possibilities in interest and marketability. In point of fact, however, practically no translation of either American or British books is done in Quebec, publishers and public here letting Parisian publishers and translators dictate what books from the English-speaking world will be put into French.

On the other hand, English-Canada has never had a clearly defined cultural policy on the translation of its own literary products or their promotion in Quebec. This laissez-faire attitude is compouned by a misguided belief in the one-way bilingualism of Quebec - the confused conviction that literate Québécois are bilingual by necessity and if they choose to read English-Canadian works will prefer to read them in the original. (I say one-way bilingualism because there does not seem to be any reciprocal expectation that English-Canadians will insist on reading works from Quebec in the original French.)

So from one side and the other come certain myths and mental blocks which have contributed to discourage the translation. of English-Canadian books in Quebec. The situation, as we shall see, is somewhat better on the English side, but here too the same lack of knowledge, of interest, even of curiosity, creates similar obstacles to sustained and bold cultural exchange through the medium of translation.

With this much as preamble let us now look at the actual record, beginning with the genre of fiction, and looking first at French translations.

7. The Bibliography (1975) lists 250 English translations, 120 French. The revised edition will include about 370 titles in English, 180 in French. 
In the 19th century the following titles were translated : Frances Brooke's The History of Emily Montague (1809), selections from Haliburton's The Old Judge (1849), Rosanna Leprohon's Antoinette de Mirecourt (1865), and Kirby's The Golden Dog (1884), the first two published in Paris, the latter in Montreal, all but the last long out of print. Although with hindsight one misses works by Richardson, Moodie, Duncan, Connor, Roberts and several others, this is not a bad representation of a somewhat meagre harvest, and compared to the records of Quebec translations of works of the 20th century, it is even rather generous. Among the 19 novelists translated from 1900-1970 (of whom only 10 could be said to be at all important), three giants stand out : Arthur Hailey, Malcolm Lowry and Mazo de la Roche. Titles by these three account for over half the English-Canadian novels translated. All these works were published in Paris or Geneva. With due respect for their talent, the status of these three as representing 20th century English fiction in Canada, or even half of it, is highly doubtful. ( $\mathrm{I}$ am reminded of being told by a visiting Soviet cultural delegation that Canadian literature was well known in the USSR thanks to Russian familiarity with Ernest Thompson Seton, Wilson MacDonald and Joe Walsh.) Before 1960 no significant novel was translated. In the sixties and early seventies, besides the flood of HaileyLowry-de la Roche, three novels by MacLennan and Richler became available, two volumes each of Leacock and Leonard Cohen, and The Fire-dwellers by Margaret Laurence. If we except Lowry and Laurence, no writer domiciled west of Toronto was translated, and of the 45 novels published from 1900 to 1970 , only 8 were published in Quebec. In 1973, the Montreal publishing house Cercle du Livre de France began a translation series, "Collection des Deux Solitudes ». This has widened the range of English-Canadian fiction in translation to include single works by Emily Carr, Constance Beresford-Howe, Robertson Davies, another Margaret Laurence, Roy MacSkimming, W.O. Mitchell, two by Calaghan and two more by Richler. Half a dozen other translations are in the works. When they are out, publisher Pierre Tisseyre will review the success of the whole venture and decide whether it is worth while going on.

This initiative is praiseworthy but an attempt to provide a typical selection of English-Canadian fiction is perhaps more than one publisher can handle. A fairly representative list would include works by older novelists, F.P. Grove, Hugh Garner, Brian Moore, Sinclair Ross and Ethel Wilson, none of whom have been translated ; more fiction by Callaghan, Davies, Laurence, Leacock and MacLennan; some regional novels : by Buckler and Raddall from the Maritimes, for instance ; by Kreisel, Ostenso, Marlyn, Salverson or Stead from the prairies ; some single masterpieces such as Klein's The Second Scroll, McDougall's Execution or O'Hagan's Tay John; and several collections of short stories, not to mention numerous works by the present generation of writers: Atwood, Blaise, Engel, Gallant, Gibson, Godfrey, Hood, Kroetsch, MacEwen, Metcalf, Munro, Nowlan, Smith, Wiebe, Wiseman and Wright, none of whom have yet been properly exposed to Quebec readers through translation. It may be tedious to enumerate all these possibilities, but it is important to realize that to deny access to such writers by default of translation is the equivalent to being unfamiliar with Aquin, Blais, 
Carrier, Ducharme, Ferron, Godbout, Hébert and other Quebec writers who are well known through English translations today.

As I have suggested, since twice as many French titles have been translated, representation of Quebec fiction is much more complete. While only 7 nineteenth century titles have been translated, the record between 1900 and 1960, when 32 Quebec novels were translated as opposed to 12 from English, is much better. Better, too, the record since 1960 with 78 novels by 38 novelists added for a total of 117 works of fiction by 51 writers. English-language publishers have had their favorites among Quebec novelists too, for works by Marie-Claire Blais, Roch Carrier, Louis Hémon and Gabrielle Roy make up almost one-quarter of all the fiction translated. (13 of these titles, 5 by Blais, 4 by Hémon, 4 by Roy, were just published in the U.S.A.) But by now a dozen Quebec writers have had three or more novels Englished, another 8 have had two works translated. In other ways the situation is, relatively speaking, more sophisticated : in several cases there are two translations of the same work; many titles have been reissued in paperback, and more experimental fiction has been tried.

Of course much remains to be done : more translations and retranslations of older works are needed; many out-of-print titles should be revived; some significant omissions should be corrected, among these works by older writers Réal Benoit, Madeleine Ferron, Louise Maheux-Forcier, J.J. Richard, and Jean Vaillancourt and new novels by Jean Basile, Jacques Poulin and André Major as well as the untranslated works of Bessette, Ducharme, Ferron, Godbout, Langevin, Leclerc and a few others. On the whole, however, it is possible for the anglophone reader to get a fair idea of the Quebec novel from works available in translation ${ }^{8}$.

In other genres the story is more quickly told. As far as French translations of English poetry and drama are concerned, the field is virgin. In poetry, while saluting the work of Ellipse, the review which in the past seven years has published 19 issues devoted to translations of contemporary poets, one must note the urgent need of an anthology to parallel John Glassco's The Poetry of French Canada in Translation. Admittedly, poetry is more difficult to translate than prose, but it can and should be tried, especially when poetry is Canada's strongest genre in both English and French. Many English-Canadian poets - Fred Cogswell, G.V. Downes, John Glassco, George Johnson, Doug Jones, F.R. Scott and A.J.M. Smith to name a few - have turned their talents to translating Quebec verse. Very few Quebec poets have reciprocated.

In drama, despite a strong upsurge of activity in the late sixties and early seventies, with the exception of two plays (Herbert's Fortune and Men's Eyes and McDonough's Charbonneau and le Chef), no works from English Canada have

8. The question of availability is a nasty one. Publishers are in the habit of printing shortrun, expensive editions, for they still consider translations to be luxury items, diplomatic or political gestures and always as marginal. Only one English publisher, Harvest House of Montreal, has made a concerted effort to produce cheap editions and to promote translations as translations. 20 titles are now available in the * French Writers of Canada * series. Another 15 titles are available in paperback scattered among McClelland and Stewart's * New Canadian Library * series. 
been either published or played. One may be ready to accept the argument that an equally strong group of young Quebec playwrights absorbs all the energies and facilities of the Quebec stage. But when one sees the room made for translations and adaptations of English and American plays (Goldsmith, Shaw, Coward, O'Neill and Tennessee Williams were played in French this season in Montreal) one wonders why no consideration has yet been given to mounting French versions of new plays by Fennario, Freeman, French, Reaney or Ryga.

On the English side the situation is somewhat better. Twenty Quebec plays are now available in translation (6 of these by Michel Tremblay). This scarcely represents the wealth of contemporary Quebec Theatre, but it is at least a start. As for poetry, 19 translations of individual poets have been published and besides the contemporary verse contained in Ellipse, there are four anthologies ${ }^{9}$ devoted exclusively to Quebec poets while selections are included in a dozen more. This compares to four translations of individual poets from English to French (two of Leonard Cohen published in France, an adaptation of Colombo's The Great Wall of China, and a bilingual edition of verse by Richard Sommer), and, in lieu of anthologies, two samples of English-Canadian verse published in the Paris review les Lettres Nouvelles (Dec. 1966) and Montreal's Liberté (May, 1960.) Finally, in regard to English translations of poetry one should note the possibility of comparative study thanks to translations of major Quebec poets by several hands and the interesting exchange of correspondence between poetess Anne Hébert and her translator, F.R. Scott, in Dialogue sur la traduction à propos du «Tombeau des rois ».

As for the category listed in the bibliography as «Essay (non-fiction), several observations are necessary. First, it is the largest category on both sides, representing $40 \%$ of the overall production of literary translations, as opposed to $35 \%$ for fiction. On the French side, «Essai » represents $50 \%$ of total, « Roman 》 another $40 \%$. Apart from translations of nine books by or about McLuhan, the range of subjects is fairly evenly distributed among political essays, history and biography, and works of a general nature. In the past, almost half of the nonfiction translated in Quebec has had Quebec as subject, but recently publishers have been slightly more extrovert and the number of general titles is increasing. As for English translations from the French, subjects are divided in roughly the same way. The emphasis is, however, less self-scrutinizing. Almost $60 \%$ of the titles focus on Quebec, whereas only $20 \%$ of French translations deal with Canadian affairs outside the province.

It is obvious from this analysis that translation from French to English is better developed than in the reverse direction : more works, better variety, more anthologies, more retranslations and reprints are available. Still one can hardly hold up English practice as a model, for the library of Quebec literature in translation is far from complete : over and above specific gaps already mentioned, many

9. Speaking of anthologies of literature in general, only 3 exist in French, all out of print, whereas this category contains 40 titles in English. In all justice one must add that the majority of these, going under the name of anthologies of Canadian literature, include no more than two or three token selections from Quebec. 
works of history, art history and literary criticism ${ }^{10}$ remain untranslated ; the whole domain of the social sciences should be carefully reviewed; the quality of some translations is inferior, others should be updated ; those that are still adequate should be reissued in cheap editions.

This sobering and somewhat gloomy appraisal of the situation should probably be corrected by looking, not so much at what has not been done and at what might be done, as at what has actually been accomplished over the last few years. For it is a fact that the rate of literary translation in Canada has risen rapidly since 1960. Since that date more translations have been published than during all the years before, and every five years the number of books translated has doubled. The incentives for this increased activity have been provided by the Canada Council's translation programme which, informally since the early sixties and more systematically since 1971 has given grants to Canadian publishers covering the cost of the translator's fee for translation of Canadian books and, in a few cases, of books by Canadian writers published abroad. Some 250 titles have been subsidized, in this way over the past 15 years (over 200 since 1971) with grants totalling more than half a million dollars. The programme is, on the whole, well administered and, while permitting publishers to add translated titles to their lists at relatively low cost, it has encouraged many writers to try translation. Of the 55 Canadians who have translated two books or more, 40 of them have received Canada Council grants.

Also in an effort to promote translation and to encourage excellence, in 1974 the Council inaugurated a Translation Prize of $\$ 2500$ (raised to $\$ 5000$ in 1976) to be awarded to the two best translations of the year, one in French, one in English. The winners have been Alan Brown and Jean Paré (1974), Sheila Fischman and Michelle Tisseyre (1975), John Glassco and Jean Simard (1976).

In 1974 the Canada Council also sponsored a week-long meeting at Stanley House in Gaspésie where a dozen translators laid plans for the foundation of a new translators' association. L'Association des traducteurs littéraires/Literary Translators' Association was officially constituted at a meeting held in Montreal in May 1975. It now groups 43 members (27 English, 16 French) and, under the presidency of Patricia Claxton, pursues the following aims :

- to ensure high standards of quality in literary translation;

- to foster an awareness and appreciation of the value of excellence in translation ;

- to provide literary translators with a forum for the exchange of information and ideas ;

- to define, establish and protect the professional rights of literary translators ${ }^{11}$.

It is fitting to end this survey with the translators themselves. Though by no means a homogeneous group, they now have a collective sense of identity and consider themselves closer to Canadian writers than to their commercial or bureau-

\footnotetext{
10. Only two works of literary criticism have been translated : Klinck's Histoire littéraire du Canada (1970) and Tougas' History of French-Canadian Literature (1966)

11. From the ATL/LTA Constitution.
} 
cratic colleagues. They are talented and well-educated people drawn largely from university, communications or publishing circles. Besides serving the community through the quality of their work, thanks to their knowledge of the other culture they have frequently acted in an advisory capacity to Canadian publishers and have initiated many translation projects themselves. Translation is a part-time occupation for most of them, for it is still an extremely precarious profession ; at the present time perhaps only two or three Canadians rely principally on literary translation for their livelihood.

The future of this kind of translation in Canada, as the Association recognizes, rests in their hands. If they continue to produce good work, to be well informed about what is being done about the possibilities of future translation, and if they actively promote the cause of translation in Canada, there will be a future. Otherwise translation will sink under the inertia of the mutual indifference of Frenchand English-speaking Canadians towards one another. Above all, by their example and enthusiasm literary translators must encourage younger writers and scholars to become practitioners of this art which, beyond all political considerations, enriches both the artist and the artist's public by opening minds to new areas and new opportunities of exchange.

Philip Stratford 